\section{Social Work} \& Education

CSW\&E, 2021

УДК 159.9

DOI: $10.25128 / 2520-6230.21 .2 .2$.

\section{Артем Бордійчук,}

студент 4 курсу, спеціальність «Соціальна робота», ЗВО «Український католицький університет»,

м. Львів, Україна;

bordichuk@ucu.edu.ua
Бордійчук, А. 2021). Самотність та соціальна ізоляція людей похилого віку під час пандемії covid-19: фактори, що їх спричиняють. Social Work and Education, Vol. 8, No. 2. pp. 152-163. DOI: $10.25128 / 2520-6230.21 .2 .2$.

\section{САМОТНІСТЬ ТА СОЦІАЛЬНА ІЗОЛЯЦІЯ ЛЮДЕЙ ПОХИЛОГО ВІКУ ПІД ЧАС ПАНДЕМІЇ COVID- 19: ФАКТОРИ, ЩО ЇХ СПРИЧИНЯЮТЬ}

\section{Cmamyc cmammi:}

Отримано: квітень 08, 2021

1-ие рецензування: травень 24, 2021

Прийнято: травень 30, 2021
Ключові слова: самотність; соціальна ізоляція; люди похилого віку; пандемія COVID-19. 


\section{Вступ}

Похилий вік - це період життя, коли людина стає вразливою до навколишніх змін, через брак особистісних і матеріальних ресурсів, які $є$ критично важливими для профілактики й протидії негативним змінам у зовнішньому середовищі. Зауважимо, що в України кожний п'ятий громадянин належить до категорії людей похилого віку. Важливо пам'ятати, що українські пенсіонери $\epsilon$ представниками даної категорії населення. До того ж за останні роки в розвинутих країнах світу зросла кількість літніх людей (Визначення віку, з якого особа може вважатися особою похилого віку..., 2021). Подібні факти вкотре підсилюють нагальність та важливість проблем 3 якими зіштовхнулися представники даної категорії населення під час пандемії COVID-19.

Наше дослідження - це свого роду аналіз явищ самотності та соціальної ізоляції серед людей похилого віку до та під час пандемії COVID-19. Нам вдалося дослідити вплив зазначених проблем на фізичне, психологічний та емоційне здоров'я представників досліджуваної групи. Надзвичайно важливою частиною нашої роботи $€$ аналіз взаємозв'язку між виокремленими індикаторами (факторами) та досліджуваними явищами самотності й соціальної ізоляції, які безпосередньо впливають на добробут людей похилого віку в умовах пандемії COVID-19. Зауважимо, що нам вдалося ідентифікували низку інших викликів 3 якими зіштовхнулися представники даної категорії населення під час пандемії COVID-19, яка, між іншим, триває досі.

Наукова актуальність дослідження полягає в тому, що представники інтелектуальної спільноти, тобто науковці лише почали вивчати та систематизувати інформацію про вплив пандемії COVID-19 на фізичну, психологічну та емоційну сферу життя людей похилого віку. Саме тому результати дослідження проблем самотності та соціальної ізоляції серед літніх людей під час пандемії COVID-19 слугуватимуть фундаментом для розробки стратегій i рекомендацій щодо реабілітації представників даної категорії населення.

Насмілимося припустити, що результати нашого дослідження сприятимуть гарантії загальнолюдських прав осіб похилого віку. Тому що, кожний громадянин України має право на соціальний захист і допомогу у вирішенні складних життєвих обставин, яку повинна забезпечити держава. Біліше того дані гарантії $\epsilon$ вкрай необхідними для вразливих категорій населення, однією з яких є група людей похилого віку. Результати нашого дослідження допоможуть краще зрозуміти проблеми самотності та соціальної ізоляції серед представників досліджуваної групи, а також сприятимуть визначенню шляхів протидії даним явищам. 
Мета статі - на основі аналізу наукової літератури з проблеми дослідження виокремити фактори (індикатори) та дослідити їх вплив на проблему самотності та соціальної ізоляції людей похилого віку під час пандемії COVID-19.

\section{Методологія дослідження}

Для досягнення поставленої мети було застосовано теоретичний метод - аналіз наукової літератури, архівних джерел, документації та продуктів діяльності 3 метою їх порівняння, структурування, узагальнення задля вивчення сутності, специфічних особливостей та характеру впливу основних понять дослідження: «самотність», «соціальна ізоляція», «пандемія», на людей похилого віку. В основі нашого емпіричного дослідження був застосований діагностичний метод інтерв'ювання. Інтерпретували результати дослідження за допомогою статистичних методів: технічний транскрипт, аналітичне кодування, інтерпретація сенсу.

Пошук наукових джерел здійснювали у передових наукових базах даних: Google Scholar та ReasearchGate, Web of Science тощо. Шукали за допомогою ключових слів англійською (characteristic features, impact, social isolation, loneliness, elderly, pandemic, COVID-19) та українською (характерні особливості, вплив, самотність, соціальна ізоляція, пандемія, коронавірус), застосовуючи їх різноманітні комбінації.

Ми здійснили вибір наукових джерел для подальшого їх опрацювання на основі переліку сформованих критеріїв: відповідність темі дослідження; дата публікації; наявність списку літератури та посилань на первині джерела. Одиницею аналізу наукових праць були частини наукових текстів, які відповідали темі та визначеним категоріям дослідження: проблема самотності літніх людей; проблема соціальної ізоляції людей похилого віку; вплив пандемії COVID-19 на людей похилого віку.

\section{Аналіз досліджень і публікацій}

Самотність та соціальна ізоляція є нагальними проблема “нової геронтології”, тобто науки про старіння, яка сконцентрована на процесі старіння, прогресуючих непатологічних, біологічних та фізіологічних змінах, які відбуваються в організмі людини похилого віку (Rowe, 1997). Сучасна форма науки побудована на концепції "успішного старіння" та встановлює іiі передумови та кінцевий результат, орієнтована на здоров'я та активну участь у житті й значною мірою транслює можливість кожної людини досягнути нормативно-бажаного стану в похилому віці (Martha, Meredith, 2003; Rowe, 1997).

Дефініцію “самотності” та особливості даного явища визначили Петровський А. В. та Ярошевська М. Г. (2013) у психологічному словнику власної редакції; Вербицька С. Л. у власному дисертаційному дослідженні. Кізіма В. В. (2014) 
дослідила різні підходи до визначення та розуміння явища самотності; Хамітов Н. В. описав два види самотності: зовнішню та внутрішню та причини їх виникнення; Hawkley L. C. та Cacioppo J. T. (2010) пояснили самотність через призму кількісного або якісного незадоволення соціальних потреб особистості. Lubkin I. M. та Larsen P. D. (2006) визначили самотність, як частину концепції соціальної ізоляції; Лазарець М. (2020) пояснив самотність в контексті соціального неприйняття; Тополь О. В. (2007) описав явище самотності у літньому віці; Подорожний В. Г. (2017) визначив самотність, як проблему людей похилого віку; Ткачук С. П. (2019) визначив соціальний контекст переживання самотності людьми похилого віку; Crewdson J. А. (2016) описав ефект самотності на людей похилого віку.

Рєвнівцева О. В. (2008) дослідила та систематизувала різні підходи у визначенні та розумінні явища соціальної ізоляції; Біорді Д. Л. та Ніколсон Н. Р. (2006) визначили соціальну ізоляцію, як втрату місця в межах власної групи (2006); Cacioppo J. T., Hawkley L. C. (2010), Norman G. J., Berntson, G. G. (2011) опрацювали результати лонгітюдних досліджень щодо потенційно незрозумілих змінних (негативність, депресивна симптоматика та інше) та їх взаємозв'язку 3 поведінковими, нервовими, гормональними та іншими ефектами ізоляції у людей (2011).

Morens D. M., Folkers G. K., Fauci A. S. (2009) сформували дефініцію терміну “пандемія” та визначили характерні особливості даного явища; Пода Т. А. (2020) дослідила вплив пандемії COVID-19 на систему міжнародних відносин; Грущинська Н. (2020) - трансформації, що відбуваються у світових процесах під впливом COVID-19; Леушина О. А. та Верховод I. С. (2020). визначили вплив пандемії на парадигми розвитку сучасного суспільства; Сидоренко О. (2020) у власній статті описав взаємозв'язок між людьми похилого віку та пандемією; Girdhar R., Srivastava V., Sethi S. (2020) дослідили вплив пандемії COVID-19 на психологічне здоров'я людей похилого віку; Бихкало Л., Літвінова О. В. (2020) вплив пандемії COVID-19 на емоційні стани людей похилого віку; Pelicioni P. H., Lord S. R. (2020) - вплив пандемії COVID-19 на різноманітні сфери життя літніх людей; Petretto D. R., Pili R. (2020) дослідили взаємозв'язок між явищем ейджизму та пандемією COVID-19.

Результати останніх досліджень продемонстрували негативний вплив явищ самотності та соціальної ізоляції на фізичне та психологічне здоров'я літніх людей. До того ж когнітивна сфера представників цільової групи зазнає негативних змін під впливом зазначених явищ. Важливо, що до пандемії COVID19 явище самотності у літніх людей було обумовлене віком, відмовою від певних соціальних ролей, фактором виходу на пенсію, деградацією комунікативних та адаптивних навичок особистості. Зауважимо, що саме карантинні обмеження введені під час пандемії COVID-19 були підгрунтям для виникнення проблеми 
соціальної ізоляції в житті літніх людей. Оскільки вони порушили основні соціальні мережі представників досліджуваної групи. Цікаво, що під час пандемії COVID-19 явище самотності було наслідком соціальної ізоляції. Проте, у більшості досліджень здійснених до пандемії COVID-19 взаємозв'язок між даними явищами в житті людей похилого віку був діаметрально протилежним.

\section{Основна частина}

\section{Опис емпіричного дослідження}

Ми здійснили емпіричне дослідження у формі інтерв'ю за допомогою засобу мобільного зв'язку. Зауважимо, що усі респонденти погодилися на здійснення аудіозапису розмови, середня тривалість якої сягала $15-20$ хвилин. Респондентами були представники цільової групи, тобто особи похилого віку. Серед них троє жінок у віці 65, 69, 70 років і двоє чоловіків 73 та 74 років відповідно. Ми ставили за мету визначити роль заздалегідь виокремлених індикаторів (факторів) дослідження у процесі формування явищ самотності та соціальної ізоляції серед представників досліджуваної групи.

Відповідно до мети, було сформоване завдання, яке полягало у визначенні взаємозв'язку між визначеними факторами (індикаторами) дослідження та явищами самотності й соціальної ізоляції. Зауважимо, що ми дотрималися принципу конфіденційності, оформляючи результати дослідження.

Ми визначили індикатори (фактори) нашого дослідження на основі проведеного аналізу наукових праць Girdhar R., Srivastava V., Sethi S. (2020), Ткачук С. П. (2019), Тополь О. В. (2007), Лазарець М. (2020) та Подорожний В. Г. (2017). Нам вдалося виокремити наступний перелік передумов виникнення самотності та соціальної ізоляції в представників досліджуваної категорії населення:

1) Вимушена відмова від багатьох соціальних ролей (через вік, факт виходу на пенсію тощо).

2) Різке скорочення кола спілкування.

3) Порушення соціальних відносин, соціальної взаємодії.

4) Зменшення активної життєдіяльності.

5) Наявність великої кількості вільного часу та відсутність якості його наповнення.

6) Припинення трудової діяльності.

7) Втрата соціального статусу, соціальної ролі.

8) Почуття незадоволеності від взаємозв'язків з друзями, родичами тощо.

9) Деградація адаптивних здібностей та комунікативних навичок, через вік літніх людей тощо. 
Зауважимо, що причини зазначені в пунктах з 1-6 є особливо актуальними в період пандемії COVID-19, яка, між іншим, триває досі. Ірвін Ялом запропонував класифікацію явища самотності, відповідно до типу ізоляції:

1) “спричинену емоційною ізоляцією - через відсутність прив'язаності до конкретної людини або коли людина відокремлює свої емоції від спогадів про подію та стає нездатною до близьких стосунків з іншими людьми;

2) спричинену соціальною ізоляцією - відсутність доступного кола спілкування осіб, здатних задовольнити потребу у спілкуванні як такому, в міжособистісних контактах" (Лазарець М., 2020).

Беручи до уваги вищесказане, ми сформували наступні фактори (індикатори) емпіричного дослідження:

1. "Наявність родичів та друзів і зв'язку з ними".

2. "Наявність співмешканців".

3. "Наявність підтримки членів родини/друзів/співмешканців/громади".

4. “Приналежність до певних соиіальних об'єднань”.

5. "Наявність різноманітних способів комунікації".

6. "Інтенсивність комунікації та взаємодії".

7. "Праиевлаштування".

8. "Участь в релігійному житті".

9. "Відчуття ізоляиії".

\section{Опис результатів дослідження}

Результати дослідження продемонстрували, що всі учасники інтерв'ю підтримують контакт з друзями та родичами. Саме тому індикатор "наявність родичів та друзів і зв'язку з ними” є важливим у межах нашого дослідження. До того ж респонденти, які не відчувають себе самотніми живуть зі співмешканцями. I що не менш важливо, вони отримують фінансову, емоційну, психологічну та іншу підтримку від рідних і друзів:

1. "Допомагають мені мої діти в основному. Ну сусіди щось куплять, як попросити ... Донька з якою я живу все приносить, все допомагає".

2. "3 боку дітей, з боку чоловіка та друзів. В основному допомагають морально. Іще діти матеріально".

3. “... Як $і$ до пандемії, так і під час завжди приділяе час (дружина), разом читаємо віриі”.

Зауважимо, що респондент, який зізнався про наявність почуття самотності проживає самостійно. До того ж на запитання про наявність допомоги від рідних, друзів та членів громади, відповів: “Поки не потребую підтримки”.

Нам вдалося визначити канали та інтенсивність комунікації респондентів 3 рідними та друзями за допомогою індикатора "різноманітність способів комунікаціі”. Цікаво, що отримані відповіді були майже ідентичними: 
1. “Дочка приходить до мене. 3 сестрою по телефону. 3 подружками також по телефону”.

2. "По телефону, по скайпу".

3. "Телефоні розмови, зустрічі з самими близькими” "Тільки по мобільному телефоні".

4. В гості не ходимо ... Стараємося не зустрічатися, щоб не наражати на небезпеку рідних та близьких".

Ми передбачили, що даний фактор дослідження покликаний з'ясувати вміння респондентів користуватися новітніми технологіями зв'язку. Проте, більшість учасників інтерв'ю зазначили, що не володіють навичками необхідними для користування соціальними мережами в середовищі інтернет, додатками відеозв'язку тощо. Саме тому, в рамках запропонованого дослідження ми не можемо підтвердити або спростувати ефективність застосування засобів онлайн комунікації, як одного з методів профілактики явищ самотності та соціальної ізоляції літніх людей. Однак, нам вдалося підтвердити важливість мобільного зв'язку для людей похилого віку в умовах пандемії COVID-19.

"ІІнтенсивність комунікації та взаємодії" - це другий індикатор дослідження, який пов'язаний зі спілкуванням. Ми виявили, що респонденти, які не відчувають себе самотніми щоденно спілкуються з рідними та друзями:

1. "Кожного дня ... 3-5 разів. Це з кожною людиною”.

2. "Щоденно з дітьми та з друзями також".

3. "Дуже часто і на день, і на тиждень".

4. "Кожного дня спілкуюся з друзями та рідними".,

Зауважимо, що відповідь самотнього респондента була наступною: "Раз в місяць, рідко". До того ж ініціаторами розмов $є$ не лише самі респонденти, а також їхні родичі та друзі.

Нам вдалося 3'ясувати, що середня тривалість бесід учасників інтерв'ю є надзвичайно різноманітною, від 5 хвилин до однієї години. Саме тому, ми висновуємо, що в межах нашого дослідження фактор “інтенсивність комунікації та взаємодії” є важливим 3 точки зору частоти, а не тривалості розмов людей похилого віку.

Ми не отримали вичерпної інформації для фактора “приналежність до певних соціальних об'єднань в громаді”. Через неоднозначність відповідей респондентів:

1. "Ну до пандемії займалася в "Турботі", вивчала англійську мову, ходила на танці. Зараз це припинилося (під час пандемії)”.

2. “Літературне об'єднання ... Катастрофічно, майже не збираємося. Можемо лише через телефон чутися. Раніше їхали за кордон, до пандемії. Прийдеться все розпочати спочатку".

3. "Нi, не беру участі в ніяких спілках". 
4. “Нi, я живу дуже скромно. 3 дому не виходжу, громадською роботою не займаюся”.

Проте, ми наголошуємо на тому, що люди похилого віку, які були активно залучені в життя громади до пандемії COVID-19, втратили таку можливість 3 iï початком. Отож, певним чином зріс рівень їх відокремленості від світу.

Для того, щоб зібрати інформацію для індикатора“відчуття ізольованості”, ми дізналися про розпорядок дня учасників інтерв’ю до та під час пандемії COVID19:

1. “Я прокидалася раніше, готувала їсти, більше ходила на вулищю, базар, в магазини. Робила вдома зарядку (до пандемії) ... Тепер в пандемію роблю зарядку, в магазини не ходжу. На вулицю ходжу раз в тиждень. До пандемії іше лікувалася на стаціонарі. Тепер я вже нікуди не ходжу”;

2. "Мені, здається, щзо у мене нічого не змінилося, за винятком зимового періоду. Я гуляю, як і гуляла. І все роблю так, як і робила. Прокидаюся, іду гуляти, снідаю, вимірюю тиск, готую обід, знову іду гуляти, обідаю та відпочиваю, читаю, готую вечерю і лягаю спати";

3. "До пандемії так само як і під час пандемї прокидаюся зранку о 7, снідаю та знаходжу собі зайняття по дому, на дачі. Після обіду спілкуюся з друзями. I так майже до вечора день проходить монотонно ... вмикаю телевізор, читаю”;

4. “До пандемії ставала зранку, трошки бігла на роботу (підробіток). Трошки більше спілкувалася з людьми, було якесь цікавіше життя ... Тихо все, пенсія та більие нічого (під час пандемії)".

Зауважимо, що відповідь самотнього респондента була наступною: “Тоді (до пандеміiі) було спокійніше, ніж зараз. Більше не спілкуємося, ходимо в масках по хліб. Тримаємося більше в хаті від суспільства".

Також респонденти зазначили, що відчувають себе відірваними від своїх друзів та родичів під час пандемії COVID-19:

1. “Так, я не зустрічаюся з сестрою, з друзями, ні з ким. Окрім своїх дітей”.

2. “Відрізаним від друзів не відчуваю, а від світу таки майже без зв 'язку. Тому щзо за кордон збирався минулого літа - не потрапив. Сестра, яка мала приїжджати кожний рік з Італії-не приїхала ... “.

3. “Звичайно відчуваєш. Ще і як відчуваєш ... Бракує спілкування”.

4. Так, так, так! Як прийшов карантин - це стало дуже помітно та відчутно”.

Підсумовуючи вищесказане, стверджуємо, що учасники інтерв'ю зіштовхнулися 3 проблемою соціальної ізоляції під час пандемії COVID-19. Припустимо, що проблема виникла через карантинні обмеження, обумовлені пандемією COVID-19, та рекомендації Міністерства охорони здоров'я, щодо самоізоляції людей похилого віку. Кожний учасник інтерв'ю наголосив на відповідальному ставленні до карантинних правил в умовах пандемії.

У межах нашого дослідження, ми не змогли проаналізувати наступні фактори: “працевлаштованість”, “участь в релігійному житті”. Відповіді респондентів продемонстрували низький рівень залученості респондентів у духовне життя. Також учасники інтерв'ю зазначили, що вони не здійснюють трудової діяльності та скористалися правом виходу на пенсію. Саме тому, ми не спроможні здійснити 
аналіз та виявити взаємозв'язок між зазначеними індикаторами та явищами самотності та соціальної ізоляції в межах досліджуваної вибірки респондентів. Проте, наголошуємо на важливості майбутніх досліджень у даному напрямку.

\section{Висновки}

Отже, результати дослідження допомогли виявити позитивне значення наступних індикаторів для профілактики явищ самотності та соціальної ізоляції в середовищі людей похилого віку:

1. "Наявність родичів та друзів $і$ зв'язкуз ними”.

2. "Наявність співмешканців".

3. "Наявність підтримки членів родини/ друзів/ співмемканиів/ громади".

4. "Приналежність до певних соиіальних об'єднань в громаді".

5. "Наявність різноманітних способів комунікації" (мова йде про мобільний зв'язок),

6. "Інтенсивність комунікації та взаємодії" (з точки зору частоти, а не тривалості розмов)

Зазначимо, що у самотнього респондента не були задоволені майже усі 3 вищеперелічених факторів дослідження, за винятком першого та п'ятого. Саме тому, ми припускаємо, що відсутність ствердних даних про ці індикатори, сприяє розвитку досліджуваних проблем у літньому віці.

Наголошуємо, що позитивна характеристика індикатора “відчуття ізольованості” свідчить про те, що для людини похилого віку створенні такі умови, за яких він/вона відчуває себе відірваним/-ою від світу, родичів та друзів, тобто соціально ізольованим/-ою. Цікаво, що відповіді респондентів на запитання “Як Ви розумієте термін «самотність»?“, свідчать про те, що учасники інтерв'ю прирівнюють дане явище до соціальної ізоляції:

1. "Я думаю, що це дуже страшне. Тому що я собі не представляю, як бути самій ... Самотність - ие як тюрма".

2. "Бути без оточення, рідних, без друзів. Немає з ким спілкуватися”.

3. "Дуже трудно в самотності. Тому що раніше ми зустрічалися та спілкувалися. Зараз це заборонено”.

4. "Це коли вдома є телефон, а дзвонить будильник.

Саме тому, ми вважаємо, що за умови подальшого збереження карантинних обмежень, обумовлених пандемією COVID-19, респонденти, які не відчували себе самотніми, можуть зіштовхнутися з подібним переживанням.

Просимо звернути увагу на те, що вибірка респондентів для нашого дослідженні була нечисельною та одноманітною. Саме тому, ми не в змозі стверджувати про достовірність отриманих результатів. Крім того, не варто їх транслювати на усю категорію людей похилого віку.

\section{References}

Визначення віку, з якого особа може вважатися особою похилого віку: огляд міжнародного досвіду та національні практики. (Режим доступу, 2021). Доступ чере3: https://www.prostir.ua/wp-content/uploads/2018/12/\%D0\%9E\% D0\%B3\%D0\% BB\%D1\%8F\%D0\%B4-\%D0\%BC\%D1\%96\%D0\%B6\%D0\%BD\%D0\%B0\%D1\%80\% 
D0\%BE\%D0\%B4\%D0\%BD\%D0\%BE\%D0\%B3\%D0\%BE-

$\% \mathrm{D} 0 \% \mathrm{~B} 4 \% \mathrm{D} 0 \% \mathrm{BE} \% \mathrm{D} 1 \% 81 \% \mathrm{D} 0 \% \mathrm{~B} 2 \% \mathrm{D} 1 \% 96 \%$ D0\%B4\%D1\%83.pdf

Лазарець, М. (2020). Явище самотності як прояв соціального неприйняття. Психологія: реальність і перспективи, (15), 104-110.

Подорожний, В. Г. (2017). Самотність як проблема людей похилого віку. Загальна психологія, історія психології, (1413), 65.

Ткачук, С. П. (5-6 листопада 2019). Соціальний контекст переживання самотності людьми похилого віку. Тенденції реформування правової системи України і країн світу: правові, психологічні та соціокультурні аспекти: зб. тез доп. Міжнар. наук. конф., Тернопіль: ТНЕУ, 310-312.

Тополь, О. В. (2007). Явище самотності у літньому віці. Гуманітарний вісник Запорізької державної інженерної академії, (30), 119-127.

Girdhar, R., Srivastava, V., \& Sethi, S. (2020). Managing mental health issues among elderly during COVID-19 pandemic. Journal of geriatric care and research, 7(1), 32-35.

Iivari, J. (2010). Providing mediation as a Nationwide Service. Empirical research on restorative justice in Finland. In: Vanfraechem, I., Aertsen, I., Willemsens, J. (eds), Restorative justice realities. Empirical research in a European context (pp 95-119). Eleven, The Hague.

Lappi-Seppälä, T., Tonry, M. (2011) Crime, criminal justice and criminology in Nordic countries. In: Tonry, M., Lappi-Seppälä, T. (eds), Crime and justice in Scandinavia. Crime and justice, 40, 1-32.

Lundgaard, J. M. (2015). Norway. In: Dünkel, F., Grzywa-Holten, J., Horsfield, P. (eds), Restorative justice and mediation in penal matters, 2, $619-636$.

Lundström, B. (2013). Mediationens gennembrud. Advokaten, 13(3), 37-39.

Martha, B. H., \& Meredith, M. (2003). Self, Society, and the "New Gerontology". The Gerontologist, 43(6), 787-796. https://doi.org/10.1093/geront/43.6.787

Mayer, B. (2013). Conflict Resolution. Encyclopedia of Social Work. Retrieved from: http://socialwork.oxfordre.com/view/10.1093/acrefore/9780199975839.001.0001/ acrefore-9780199975839-e-80.

Menkel-Meadow, C. (2016). Mediation and its applications for good decision making and dispute resolution (Honorary doctorate in human sciences). KU Leuwen. Acta Falconis. Intersentia, Cambridge.

Nylund, A. (2014). The many ways of civil mediation in Norway. In: Ervo, L., Nylund, A. (eds), In the future of civil litigation. Access to court and court-annexed mediation in the Nordic countries (pp. 97-119). Springer, Cham.

Rowe, J. W. (1997). The new gerontology. Science, 278(5337), 367-368. https://doi.org/10.1126/science.278.5337.367

Salminen, K. (2018). Is mediation in the best interests of a child from the child law perspective? In: Nylund, A., Ervasti, K., Adrian, L. (eds), Nordic mediation research (pp 209-222). Springer, Cham. 


\section{LONELINESS AND SOCIAL ISOLATION OF THE ELDERLY DURING THE COVID-19 PANDEMIC}

Artem Bordichuk, Senior year student, major «Social work», Ukrainian Catholic University, Lviv, Ukraine;

Abstract. The proposed article describes the connection between the basic categories of research: loneliness, social isolation, pandemic, the elderly. Based on the analysis of Ukrainian and foreign works, the causes of loneliness and social isolation among the elderly were identified. Notably, the list of preconditions for the occurrence of the phenomena was systematized and divided into two groups: "before the COVID19 pandemic" and "during the COVID-19 pandemic". Based on the analysis of scientific studies, a list of indicators (factors) of empirical research was formed, including the presence of relatives and friends, and communication with them; the presence of cohabitants; support from family members/friends/roommates/community; participation in specific social associations; the presence of various ways of communication; the intensity (frequency and duration) of communication and interaction; employment; participation in religious life; feeling of isolation.

The study results describe the connection between the factors (indicators) and the studied problems of loneliness and social isolation among the elderly during the COVID-19 pandemic. After conducted research, we divided the indicators (factors) into two groups: "preventive" and "stimulating". The first helps to prevent the formation of loneliness and social isolation among the elderly during the pandemic COVID-19. The second, on the contrary, reinforces the negative conditions for the development of the studied problems. Also, within the proposed study, we failed to identify the role of some factors (indicators) due to the lack of information required for the analysis. Therefore, we assume that the results will help to understand the problems of loneliness and social isolation among the study group better. Note that our results will be relevant after the end of the COVID-19 pandemic. They can serve as a basis for forming strategies and recommendations for rehabilitating the elderly who have experienced social isolation and loneliness during the COVID-19 pandemic.

Key words: loneliness; social isolation; elderly; COVID-19 pandemic.

\section{Reference}

Determining the age at which a person can be considered an elderly person: a review of international experience and national practices. (2021). Retrieved from: https://www.prostir.ua/wp-content/uploads/2018/12/\%D0\%9E\%D0\%B3\%D0\% BB\%D1\%8F\%D0\%B4-\%D0\%BC\%D1\%96\%D0\%B6\%D0\%BD\%D0\%B0\%D1\%80 $\% \mathrm{D} 0 \% \mathrm{BE} \% \mathrm{D} 0 \% \mathrm{~B} 4 \% \mathrm{D} 0 \% \mathrm{BD} \% \mathrm{D} 0 \% \mathrm{BE} \% \mathrm{D} 0 \% \mathrm{~B} 3 \% \mathrm{D} 0 \% \mathrm{BE}-\% \mathrm{D} 0 \% \mathrm{~B} 4 \% \mathrm{D} 0 \% \mathrm{BE} \%$ D1\%81\%D0\%B2\%D1\%96\%D0\%B4\%D1\%83.pdf [in Ukrainian].

Girdhar, R., Srivastava, V., \& Sethi, S. (2020). Managing mental health issues among elderly during COVID-19 pandemic. Journal of geriatric care and research, 7(1), 32-35. 
Iivari, J. (2010). Providing mediation as a Nationwide Service. Empirical research on restorative justice in Finland. In: Vanfraechem, I., Aertsen, I., Willemsens, J. (eds), Restorative justice realities. Empirical research in a European context (pp 95-119). Eleven, The Hague.

Lappi-Seppälä, T., Tonry, M. (2011) Crime, criminal justice and criminology in Nordic countries. In: Tonry, M., Lappi-Seppälä, T. (eds), Crime and justice in Scandinavia. Crime and justice, 40, 1-32.

Lazarets, M. (2020). The phenomenon of loneliness as a manifestation of social rejection. Psychology: Reality and Perspectives, (15), 104-110. [in Ukrainian].

Lundgaard, J. M. (2015). Norway. In: Dünkel, F., Grzywa-Holten, J., Horsfield, P. (eds), Restorative justice and mediation in penal matters, 2, 619-636.

Lundström, B. (2013). Mediationens gennembrud. Advokaten, 13(3), 37-39.

Martha, B. H., \& Meredith, M. (2003). Self, Society, and the "New Gerontology". The Gerontologist, 43(6), 787-796. https://doi.org/10.1093/geront/43.6.787

Mayer, B. (2013). Conflict Resolution. Encyclopedia of Social Work. Retrieved from: http://socialwork.oxfordre.com/view/10.1093/acrefore/9780199975839.001. 0001/acrefore-9780199975839-e-80.

Menkel-Meadow, C. (2016). Mediation and its applications for good decision making and dispute resolution (Honorary doctorate in human sciences). KU Leuwen. Acta Falconis. Intersentia, Cambridge.

Nylund, A. (2014). The many ways of civil mediation in Norway. In: Ervo, L., Nylund, A. (eds), In the future of civil litigation. Access to court and court-annexed mediation in the Nordic countries (pp. 97-119). Springer, Cham.

Podorozhnyy, V. H. (2017). Loneliness as a problem of the elderly. General psychology, history of psychology, (1413), 65. [in Ukrainian].

Rowe, J. W. (1997). The new gerontology. Science, 278(5337), 367-368. https://doi.org/10.1126/science.278.5337.367

Salminen, K. (2018). Is mediation in the best interests of a child from the child law perspective? In: Nylund, A., Ervasti, K., Adrian, L. (eds), Nordic mediation research (pp 209-222). Springer, Cham.

Tkachuk, S. P. (November 5-6, 2019). The social context of experiencing loneliness by the elderly. Tendencies in reforming the legal system of Ukraine and the world: legal, psychological and socio-cultural aspects: Coll. thesis add. International. Science. conf., Ternopil: TNEU, 310-312. [in Ukrainian].

Topol', O. V. (2007). The phenomenon of loneliness in old age. Humanitarian Bulletin of the Zaporizhia State Engineering Academy, (30), 119-127. [in Ukrainian].

\section{Article history:}

Received: April 08, 2021

1st Revision: May 24, 2021

Accepted: May 30, 2021 